\title{
Contemporary deformation of tectonic escape in SW Taiwan from GPS observations, 1995-2005
}

\author{
Kuo-En Ching ${ }^{\text {a, } 1}$, Ruey-Juin Rau ${ }^{\text {a,* }}$, Jian-Cheng Lee ${ }^{\text {b,2 }}$, Jyr-Ching $\mathrm{Hu}^{\text {c, } 3}$ \\ a Department of Earth Sciences, National Cheng Kung University, No.1, Ta-Hsueh Rd, Tainan, Taiwan \\ ${ }^{\mathrm{b}}$ Institute of Earth Sciences, Academia Sinica, P.O. Box 1-55 Nankang, Taipei, Taiwan \\ ${ }^{c}$ Department of Geosciences, National Taiwan University, No. 1, Sec. 4, Roosevelt Road, Taipei 106, Taiwan
}

Received 20 March 2007; received in revised form 20 August 2007; accepted 20 August 2007

Available online 24 August 2007

Editor: R.D. van der Hilst

\begin{abstract}
The GPS velocity field in SW Taiwan inferred by 103 stations from 1995 to 2005 provides an opportunity to better recognize the contemporary crustal deformation under escaping tectonics. Horizontal velocities relative to the Chinese continental margin from east to west rotate counterclockwise from $42.0 \mathrm{~mm} / \mathrm{yr}$ to $13.0 \mathrm{~mm} / \mathrm{yr}$ along azimuths from $246^{\circ}$ to $265^{\circ}$ across SW Taiwan. The vertical velocity field in SW Taiwan shows a subsidence rate of 5 to $20 \mathrm{~mm} / \mathrm{yr}$ concentrated on the coastal area of the Pingtung plain and an uplift rate of 10 to $20 \mathrm{~mm} / \mathrm{yr}$ distributed along the mountain belt. Spatial velocity variation indicates the NE-SWstriking Chishan fault (CHNF) acting as reverse faulting with dextral motion, the $\mathrm{N}-\mathrm{S}$-trending Chaochou fault as nearly pure reverse faulting, and the Fengshan transfer fault zone (FTFZ) as left-lateral shearing, intersecting the aforementioned faults. The dominant WNW-ESE shortening and NE-SW dextral shear strain are subject to the fold-and-thrust belt of the Western Foothills west of the CHNF. A NE-SW extension and NW-SE contraction are represented near the FTFZ along the SW coastal area, showing a NW-SE sinistral shear strain. Our GPS data show that the movement of FTFZ greatly enhances the velocities of SW Taiwan rotating from nearly westward direction to WSW direction, sub-parallel to the edge of the basement high (i.e., the rigid indenter) of the Chinese continental margin. The Chishan fault as a boundary fault separates the SW Taiwan into a western deforming domain and an eastern quasi-rigid block. A nearly $\mathrm{E}-\mathrm{W}$ contraction and $\mathrm{N}-\mathrm{S}$ extension escaping stress regime is accommodated by $\mathrm{N}-\mathrm{S}$-trending ductile flow within the upper mantle and by brittle conjugated-type fracture, formed by the CHNF and the FTFZ, within the crust. The different directions between N-S-trending upper mantle flow and southwestward crustal escape indicate that the crust and upper mantle are decoupled in the tectonic escape process of SW Taiwan.
\end{abstract}

(C) 2007 Elsevier B.V. All rights reserved.

Keywords: GPS; tectonic escape; conjugated-fault; upper mantle flow

* Corresponding author. Tel.: +886 6275757565425 .

E-mail addresses: kuenmiao@yahoo.com.tw (K.-E. Ching), raurj@mail.ncku.edu.tw (R.-J. Rau), jclee@earth.sinica.edu.tw

(J.-C. Lee),jchu@ntu.edu.tw (J.-C.Hu).

${ }^{1}$ Tel.: +8866 275757565432310 .

${ }^{2}$ Tel.: $+886227839910 \times 413$.

${ }^{3}$ Tel.: +886223634860 .

\section{Introduction}

The concept of tectonic escape (or tectonic extrusion) around the ends of a mountain belt describes the kinematics of the lateral motions of geological units moving toward a free boundary in response to the 
collision-induced shortening, such as SE Asia (Tapponnier et al., 1982) and Eastern Alps (Ratschbacher et al., 1991). At a smaller scale in the Taiwan mountain belt, the southwestward lateral escape was also interpreted to occur in SW Taiwan, which corresponds to the southern part of a Plio-Pleistocene foreland basin developed due to the tectonic loading of the mountain belt (Fig. 1) (Lu and Malavieille, 1994; Lu et al., 1998). The shallow preTertiary Peikang basement high of the continental passive margin in central-western Taiwan acts as a convex crustal indenter with its southern edge oriented $\mathrm{N} 55^{\circ} \mathrm{E}$. The offshore NNW-trending Manila subduction zone acts as a free boundary in southwest of Taiwan. Because of the northwestward convergence of the Philippine Sea plate, the material in SW Taiwan between the Peikang high and the Manila subduction zone is forced to extrude toward WSW. Recently, Lacombe et al. (2001) and Hu et al. (2007) further proposed that the lateral escape in SW Taiwan is driven by four quasi-rigid blocks moving toward the SSW or S directions along two NNE-SSW-striking (i.e., the Chishan fault and the frontal thrust) and two N-Sstriking (the Chaochou fault and the Kaoping fault) structural discontinuities (Fig. 2), based on previous studies that include GPS observations (Hu et al., 2007; Yu and Chen, 1994; Yu et al., 1997), seismological data (Yeh et al., 1991; Wu et al., 1997; Rau and Wu, 1998), and structural analyses (Liu et al., 1997; Lacombe et al., 1999). In addition, a $\mathrm{N} 140^{\circ} \mathrm{E}$-striking sinistral Fengshan transfer fault zone (FTFZ) seemingly intersects the aforementioned major structural discontinuities in SW Taiwan according to the geomorphic analyses from drainage network anomalies, aerial photographs and satellite images (Fig. 2) (Deffontaines et al., 1997). However, the origin of the FTFZ and its relationship with major escaping-related structures (e.g., the Chishan fault and the Chaochou fault) remain obscure.

In order to strengthen the GPS coverage in SW Taiwan, which was formally limited to 11 GPS stations from Yu et al. (1997) covered entire SW Taiwan and 49 GPS stations from Hu et al. (2007) distributed within the Pingtung plain area (Fig. 3), this study adopted a new GPS array with 103 stations. This dense-spaced GPS network, that collected measurements from 1995 to 2005 , provides an opportunity to better understand the kinematics of tectonic escape in SW Taiwan. We first estimated the GPS velocity field of SW Taiwan based on GPS measurements collected from 102 campaign-mode stations and 1 continuous station between 1995 and 2005 . We then analyzed the velocity gradients across major active structures and characterized velocity discontinuities to identify the motions of these discontinuities in SW Taiwan. We also determined the internal deformation within blocks between the discontinuities. From these analyses, a new kinematic model of SW Taiwan was proposed to illustrate the crustal deformation in escaping tectonics.

\section{Geologic setting of SW Taiwan}

The Taiwan mountain belt is an ongoing arccontinent collision zone, resulting from the late Cenozoic oblique convergence between the Luzon volcanic arc of the Philippine Sea plate and the passive continental margin of the Eurasian plate (Fig. 1) (Suppe, 1984). SW Taiwan is located in the transition zone from the subduction to collision, consisting of three major structural domains (Fig. 2). The easternmost domain is the Central Range. The Eocene-to-Miocene slate and pre-Tertiary highly metamorphic rocks are the principal geological units in this domain. In addition to the prevailing ductile folding structures, numerous latestage brittle normal faults exist within the Central Range which were interpreted as a result of gravitational collapse following the exhumation of thickened crust (Angelier et al., 1995; Crespi et al., 1996). In the western portion of SW Taiwan, the structure domain is the southern tip of the Western Foothills and consists of the Miocene shallow marine deposits and the Plio-Pleistocene foreland basin. It is worth noting that a $5-\mathrm{km}$-thick mudstone of the Gutingkeng Formation (Plio-Pleistocene) is the dominant feature in this region. This foreland basin of rapid accumulated deposits was interpreted as being in response to the Plio-Pleistocene rapid mountain building and the lithospheric flexure due to the tectonic loading of mountain belt in the Central Range (Lin and Watts, 2002). Structurally, the Western Foothills of the fold-and-thrust belt comprises a series of imbricate west-vergent folds and thrusts, mixed with the pre-Tertiary basement-involved E-W-trending normal faults (Lacombe et al., 1999; Mouthereau et al., 2002). Finally, in the southern end of the Western Foothills, there exists a large alluvial plain, the Pingtung plain. The stratigraphy consists of late Quaternary marine to fluvial sediments, including fluvial deposits and coastal to estuarine sandstone and mudstone (Shyu, 1999; Chiang et al., 2004; Shyu et al., 2005). In contrast to a rapid uplift in the Western Foothills and the Central Range, the Pingtung plain subsided at rates up to $13 \mathrm{~mm} / \mathrm{yr}$ in the Holocene (e.g. Lu et al., 1998; Chiang et al., 2004; Lai et al., 2002; Lai and Hsieh, 2003).

Several major tectonic discontinuities in SW Taiwan have been documented by different disciplines of study including geological field investigations, geomorphologic analyses, and geophysical surveying. Among these 


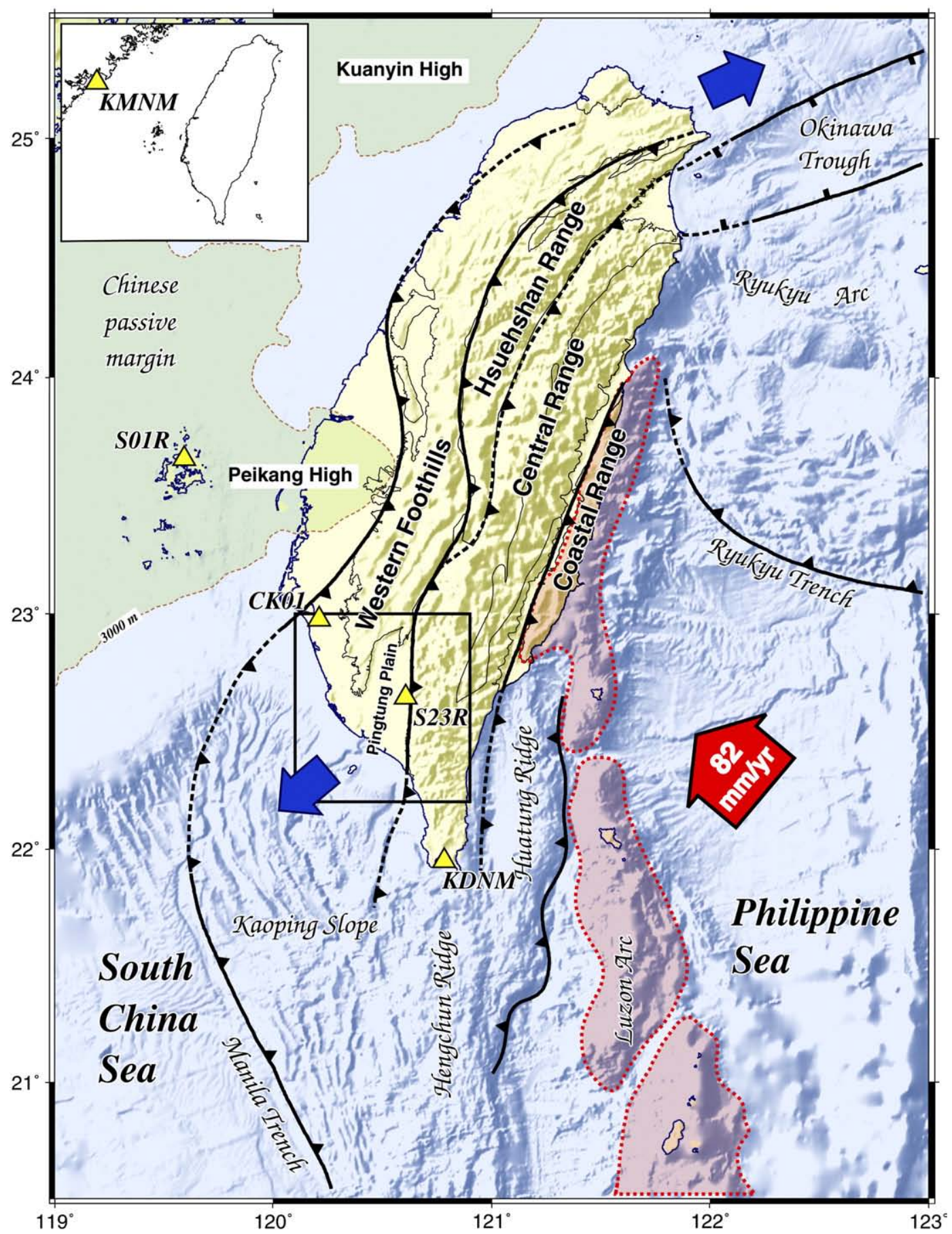

Fig. 1. Geotectonic framework and major structural units of Taiwan between the Eurasian and Philippine Sea plate. The large red arrow shows the direction and velocity of convergence between the volcanic arc and the continental margin (Yu et al., 1997). Blue arrows indicate the directions of tectonic escape. The green area denotes the location of basement high and its surrounding brown dash line indicates the 3-km-deep top of the preTertiary basement (Lin et al., 2003). Red domains are the Luzon volcanic arcs. Yellow triangles present the locations of local permanent GPS stations used in this study. The rectangle denotes the study area. (For interpretation of the references to color in this figure legend, the reader is referred to the web version of this article.) 


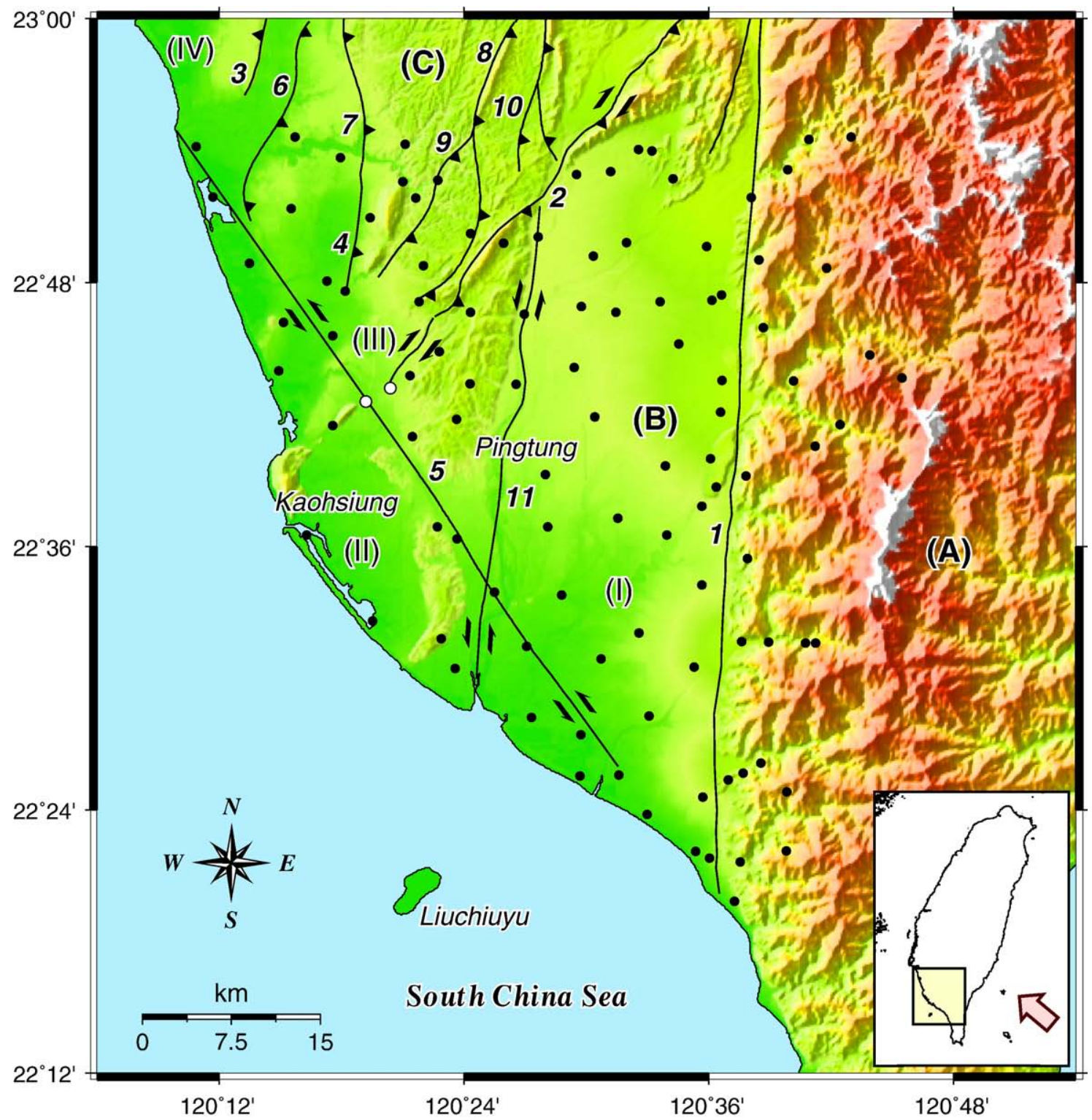

Fig. 2. Distribution of GPS stations in SW Taiwan. Small dots denote the locations of GPS monuments. Black lines are positions of active faults in SW Taiwan. 1: the Chaochou fault (CCUF); 2: the Chishan fault (CHNF); 3: the Houchiali fault (HCLF); 4: the Hsiaokangshan fault (HKSF); 5: the Fengshan transfer fault zone (FTFZ); 6: the Chungchou fault (CCF); 7: the Meilin fault (MLF); 8: the Lungchuan fault (LCF); 9: the Gutingkeng fault (GTKF); 10: the Pingchi fault (PCF); 11: the Kaoping fault (KPF). The Roman numerals, I-IV, indicate locations of quasi-rigid blocks related to the escaping tectonics proposed by Lacombe et al. (2001). Sections A to C show the positions of the Central Range, the Pingtung plain, and the Western Foothills, respectively. Topography is shown from a 40-m digital terrain model. The red arrow in the insert shows the Philippine Sea plate motion vector (Yu et al., 1997). (For interpretation of the references to color in this figure legend, the reader is referred to the web version of this article.)

discontinuities, the most remarkable surface expression is the linear $\mathrm{N}-\mathrm{S}$-trending $80-\mathrm{km}$-long escarpment of the Chaochou fault separating the Pingtung alluvial plain to the Central Range (Howard, 1962) (Fig. 2). Different interpretations have been proposed regarding the kinematics of Chaochou fault. First, this fault has been interpreted as an E-dipping reverse fault with a leftlateral component (Meng, 1967; Tsan and Keng, 1968;
Chiang, 1971; Biq, 1972; Bonilla, 1977). Second, according to the results of magnetic surveying and outcrop data, the Chaochou fault was portrayed as a basement-cutting reverse fault without a significant strike-slip component that ramped over previous deepseated normal faults (Lewis et al., 2004). Third, on the basis of the analysis of outcrop-scale faults, the eastern side of the Chaochou fault was interpreted to be under a 


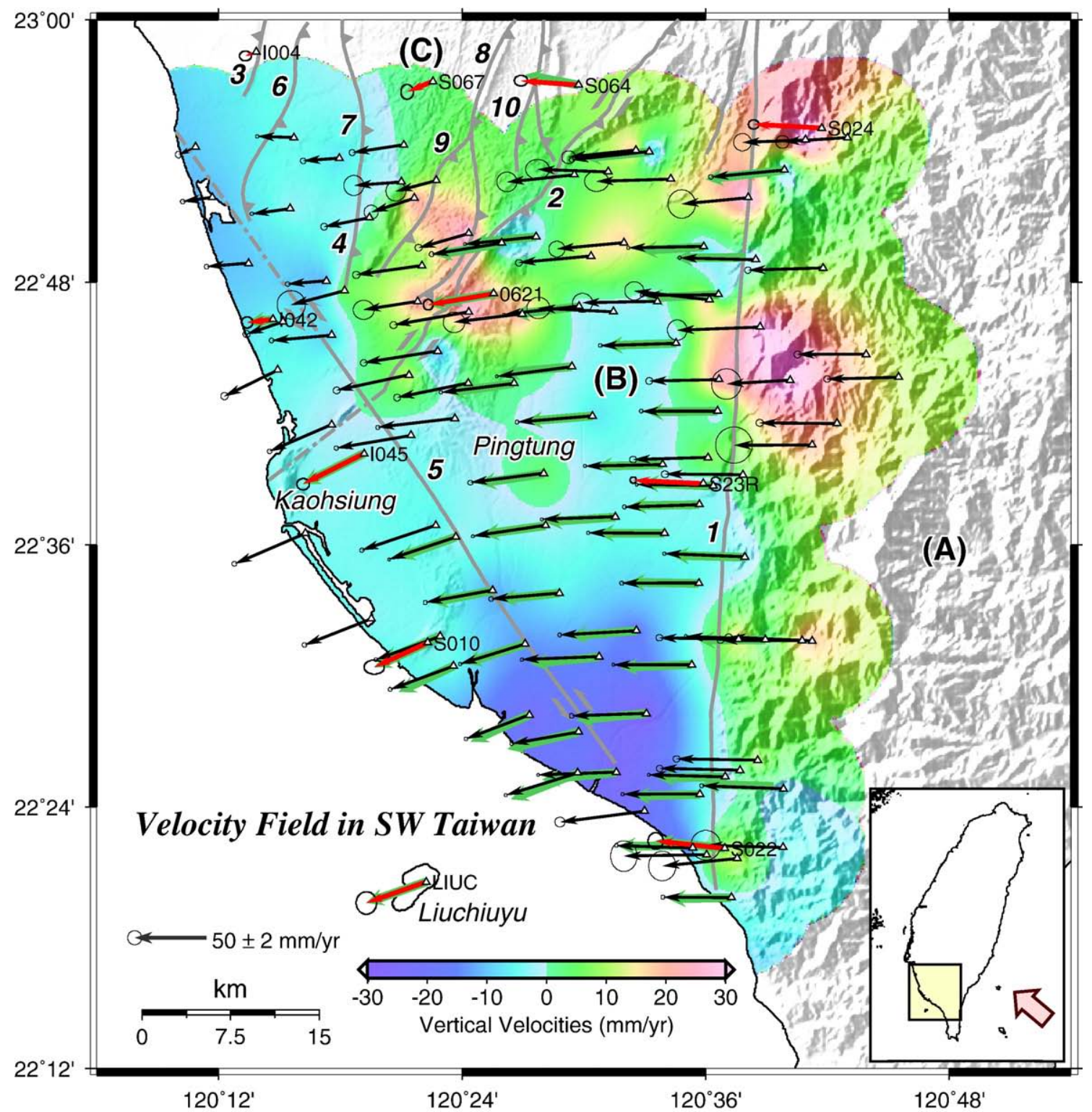

Fig. 3. The GPS velocity field in SW Taiwan with respect to the station, S01R, in the stable continental margin of the Penghu Island in the Taiwan strait. Black arrows are illustrated as the horizontal velocities of this study. Red arrows are velocities published by Yu et al. (1997). Green arrows are velocities from Hu et al. (2007). The 95\% confidence error ellipse is shown at the tip of each velocity vector. Triangles are GPS station locations. The color scale reveals the degree of vertical velocities. Gray lines are positions of active faults. (For interpretation of the references to color in this figure legend, the reader is referred to the web version of this article.)

predominantly transtensional stress regime with NNE to NE extension and ESE to SE compression (Chan et al., 2001). Finally, recent GPS data indicated that the Chaochou fault moved as a reverse fault with sinistral motion during the interseismic period (Hu et al., 2007).

The NE-SW-trending Chishan fault, a major fault with a large stratigraphic offset in the Western Foothills (Fig. 2), was interpreted as a reverse fault with a rightlateral component (Lacombe et al., 2001). A significant right-lateral component of surface motion of $24-30 \mathrm{~mm} /$ yr was inferred from the interseismic GPS velocity gradient across the Chishan fault (Hu et al., 2007). In the southwestern end of the Chishan fault where it intersects with the FTFZ, the contrast of GPS velocity across the fault becomes smoother (Hu et al., 2007).

The obscured $\mathrm{N} 140^{\circ} \mathrm{E}$-striking left-lateral Fengshan transfer fault zone was proposed as one of several NWstriking oblique structures in the Western Foothills of 
Taiwan through geomorphologic analyses (Lacombe et al., 1999; Deffontaines et al., 1997) (Fig. 2). GPS measurements from $\mathrm{Yu}$ et al. (1997) revealed that a slight left-lateral motion of about $5.5 \mathrm{~mm} / \mathrm{yr}$ occurred along the FTFZ. East of the FTFZ, the Kaoping fault (Fig. 2) was proposed by Lacombe et al. (2001) as it was an apparent seismological boundary and geomorphic expression. It is characterized by left-lateral surface motion of less than $5 \mathrm{~mm} / \mathrm{yr}$, derived from GPS observations (Hu et al., 2007). In addition, there are several reverse faults within the Western Foothills west of the Chishan fault, e.g., the Houchiali fault, the Chungchou fault, the Meilin fault, the Hsiaokangshan fault, the Gutingkeng fault, the Lungchuan fault, and the Pingchi fault, reflecting the shortening in the fold-and-thrust belt due to convergence between the Philippine Sea plate and the Eurasian plate (Fig. 2).

\section{Data collection and GPS velocity estimation}

A dense GPS array of $\sim 5 \mathrm{~km}$ station-spacing of 102 campaign-mode stations (Fig. 2) has been deployed in SW Taiwan by the Central Geological Survey (CGS) of Taiwan since 1995. This array is composed of three GPS sub-networks. One subnet of 49 stations was installed on the Pingtung plain in 1995. The second subnet of 12 stations was established in the region west of the Chishan fault in 1999. The third subnet of 41 stations was established in order to cover the area along the Chaochou fault, in 2002. We adopted 102 campaign-surveyed stations and 1 permanent station (S23R) in this network for this study. About $43 \%$ GPS data were collected more than 6 yr. About 37\% GPS data were collected between 2.5 and 6 yr. Others were collected $1-2.5$ yr. GPS surveys were generally carried out annually (Table 1 of Appendix A). In each survey, 3-10 stations were observed simultaneously with dual-frequency receivers, including the Trimble 4000 SSE, Trimble 4700, Ashtech Z-XII, Ashtech Z-Extreme, Leica SR9500, Leica SR399, Leica GX1230, and Leica SR530. During each survey, each site was usually occupied for more than two sessions and each session lasted 6-14 h. The available GPS satellites rising higher than a $15^{\circ}$ elevation angle were tracked for all GPS observations. The sampling interval for GPS data was $15 \mathrm{~s}$.

The campaign-surveyed and continuous-recorded GPS data were incorporated and processed session by session with Bernese software v.4.2 (Hugentobler et al., 2001) to obtain the precise station coordinates. The precise ephemerides provided by International GNSS Service (IGS) were employed and fixed during the processing. Four global IGS fiducial stations surround- ing Taiwan (TSKB, GUAM, TID2 and WUHN) on the international terrestrial reference frame (ITRF2000) (Altamimi et al., 2002) were used to determine the positions and velocities of four local permanent stations (CK01, S01R, KDNM, and KMNM; Fig. 1) by minimizing common-mode deviations from linear velocities. The coordinates of 103 GPS stations in SW Taiwan were then calculated from four local stations whose coordinates were derived from the a priori positions and velocities. The horizontal uncertainties of station coordinates are estimated to be $2-5 \mathrm{~mm}$. Yet, the vertical uncertainties are much larger, approximately $10-20 \mathrm{~mm}$. Because the vertical velocities in SW Taiwan reach about $25 \mathrm{~mm} / \mathrm{yr}$ (Hu et al., 2007) and more than $80 \%$ GPS data were collected over $2.5 \mathrm{yr}$, vertical velocities for most stations are still resolvable under this vertical coordinate precision.

In order to characterize the surface deformation of SW Taiwan, we first estimated secular velocities of GPS stations based on fitting the coordinate time series in a time span of $10 \mathrm{yr}$ from 1995 to 2005 with a linear function using the least-square regression method. In addition, we applied the spatial filter technique (Wdowinski et al., 1997; Tabei and Amin, 2002) to remove the common-mode errors from the coordinate time series. We first inferred the common-mode errors from the coordinate time series of 79 stations. The observed time spans of these stations are longer than $3 \mathrm{yr}$ and the number of observations for each site is larger than three times. Here we assigned the time interval between two observations longer than half a year. Average root-mean-square (RMS) scatters of the time series improve from $4 \mathrm{~mm}$ to $3 \mathrm{~mm}$ for the north component, from 7 to $4 \mathrm{~mm}$ for the east component, and from 22 to $16 \mathrm{~mm}$ in the vertical component, after filtering the raw time series. Then we applied the derived common-mode errors to filter the time series of remnant 23 stations. In addition to the uncertainties associated with the least-squares estimation of velocities (i.e., white noise $\sigma_{\mathrm{WN}}$ ), we also needed to consider the effect from "colored" or time-correlated noise (i.e., random walk noise $\sigma_{\mathrm{RW}}$ ) present in the geodetic data (Agnew, 1992). Following Langbein and Johnson (1997), we assumed the contribution of random walk noise $\sigma_{\mathrm{RW}}$ as $1 \mathrm{~mm} / t^{-1 / 2}$ for the horizontal data and $3 \mathrm{~mm} / t^{-1 / 2}$ for vertical data, where $t$ is the time span between the first and last survey in years. To estimate the total uncertainty $\sigma$ of velocity, we added a random walk noise $\sigma_{\mathrm{RW}}$ to the white noise uncertainty $\sigma_{\mathrm{WN}}$, using $\sigma=$ $\left(\sigma_{\mathrm{WN}}^{2}+\sigma_{\mathrm{RW}}^{2}\right)^{1 / 2}$. Table 1 (Appendix A) lists GPS velocity field estimates of 103 GPS stations used in the paper, covering areas of the southern Central Range, the Pingtung plain and the Western Foothills. 


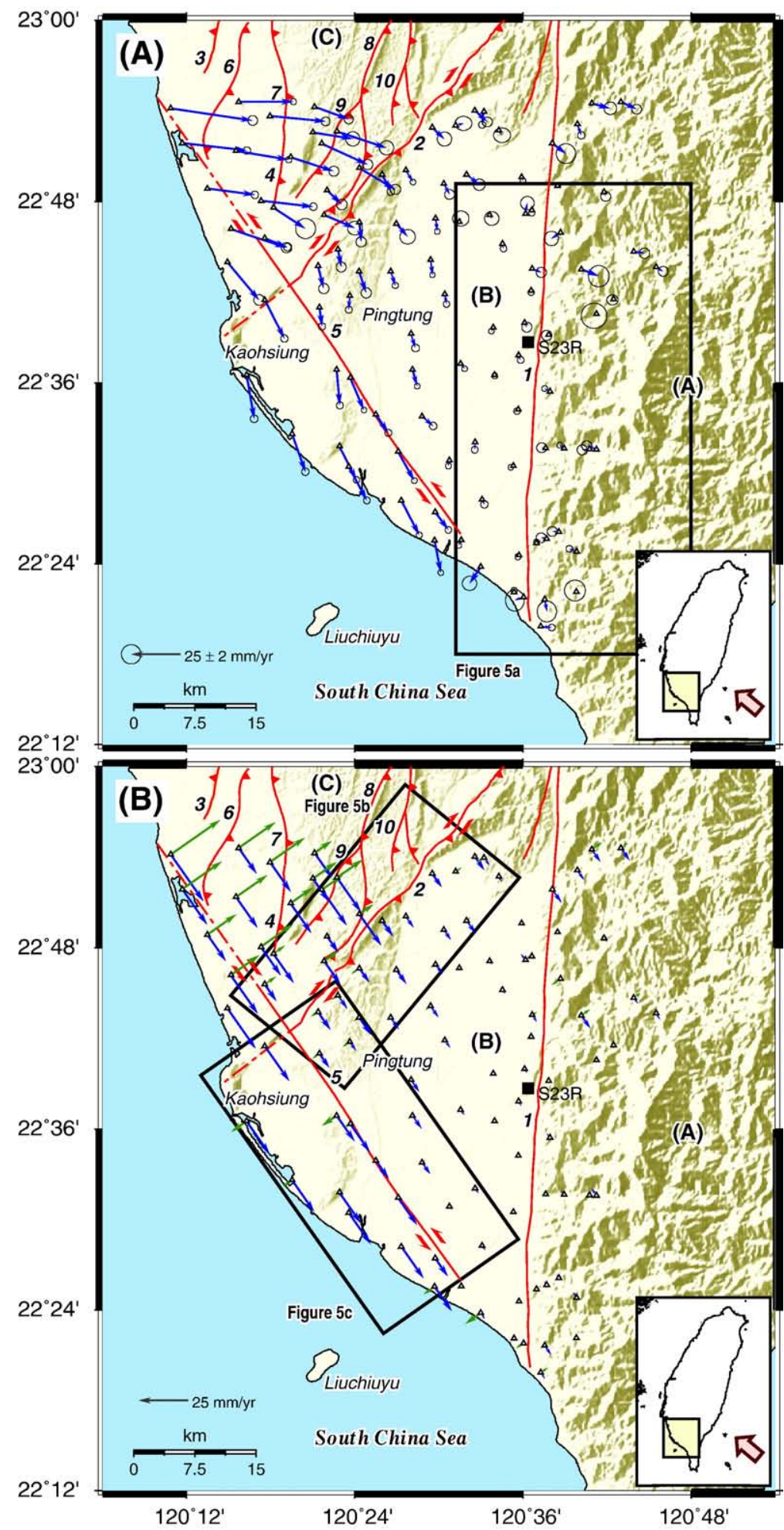

Fig. 4. (A) The horizontal GPS velocity field with respect to the station, S23R, in the Pingtung plain. Velocities are shown by blue arrows. The $95 \%$ confidence error ellipse is shown at the tip of each velocity vector. A black square indicates the position of the fixed station, S23R. (B) Decomposition of GPS horizontal velocities relative to the station, $\mathrm{S} 23 \mathrm{R}$. The blue arrows represent $\mathrm{N} 140^{\circ} \mathrm{E}$ velocity components while $\mathrm{N} 50^{\circ} \mathrm{E}$ velocity components are shown by green arrows. Red lines are locations of active faults. (For interpretation of the references to color in this figure legend, the reader is referred to the web version of this article.) 
(A) Profile across the Chaochou fault
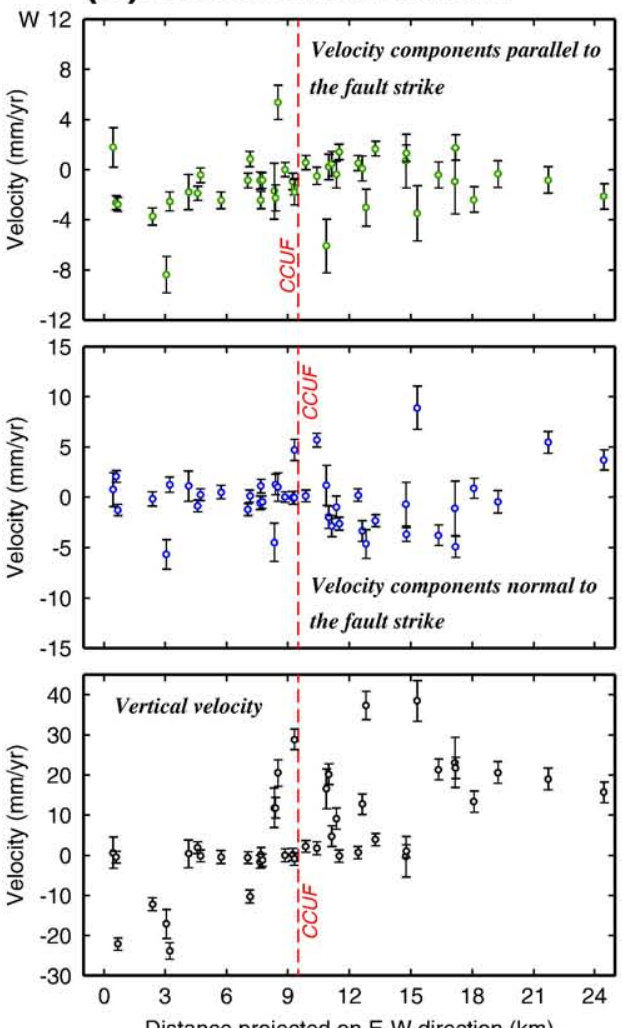

(B) Profile across the Chishan fault
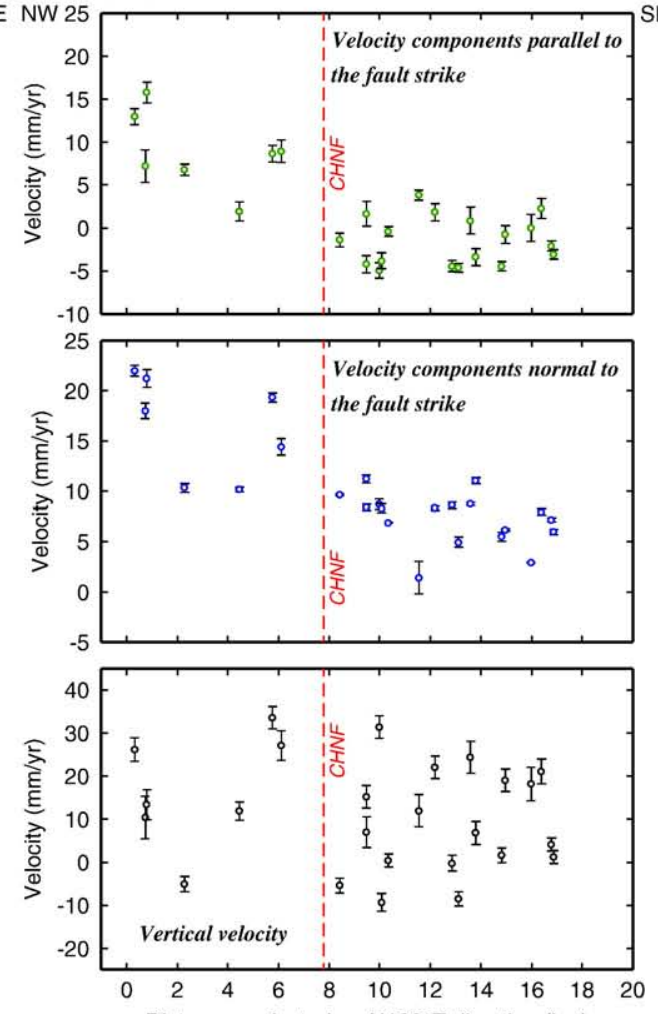

(C) Profile across the Fongshan transfer fault zone
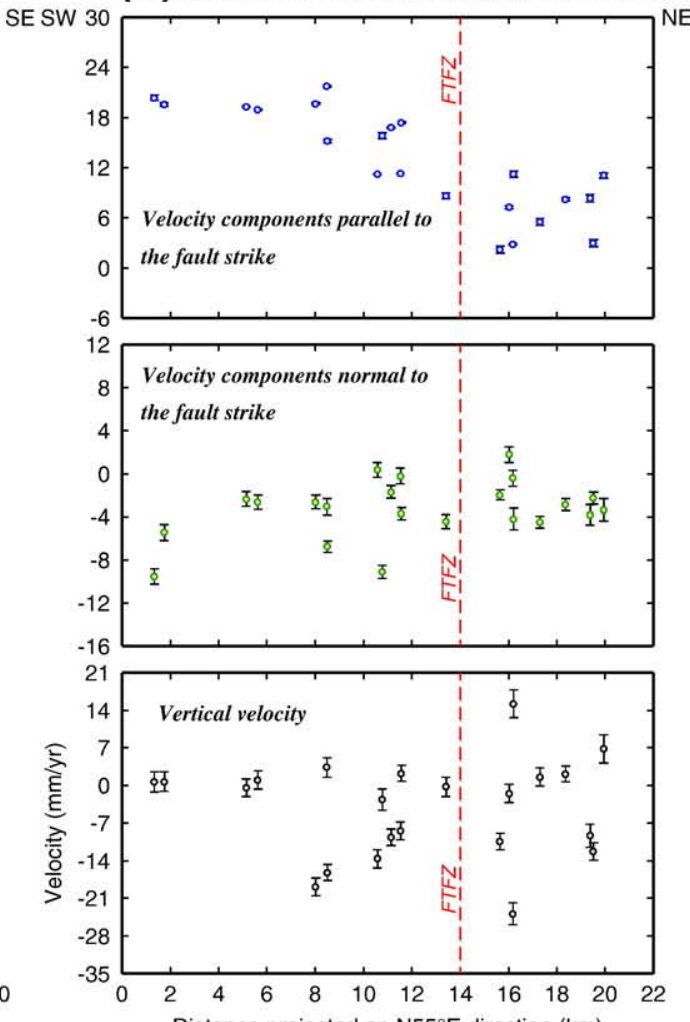

Fig. 5. Velocity profiles across three major discontinuities. Upper panels present the fault-parallel horizontal velocity components of selected stations. The central panels show the fault-normal horizontal velocity components of selected stations. The lower panels reveal the vertical velocities of selected station motions. Red lines are the locations of active faults. Note: (A) the E-W velocity profile across the Chaochou fault; (B) the N130 ${ }^{\circ} \mathrm{E}$ velocity profile across the Chishan fault; (C) the N50 ${ }^{\circ} \mathrm{E}$ velocity profile across the FTFZ. The three sub-domains are shown in Fig. $4 \mathrm{~A}$ and B. (For interpretation of the references to color in this figure legend, the reader is referred to the web version of this article.) 
(A) Principal Strain Rate

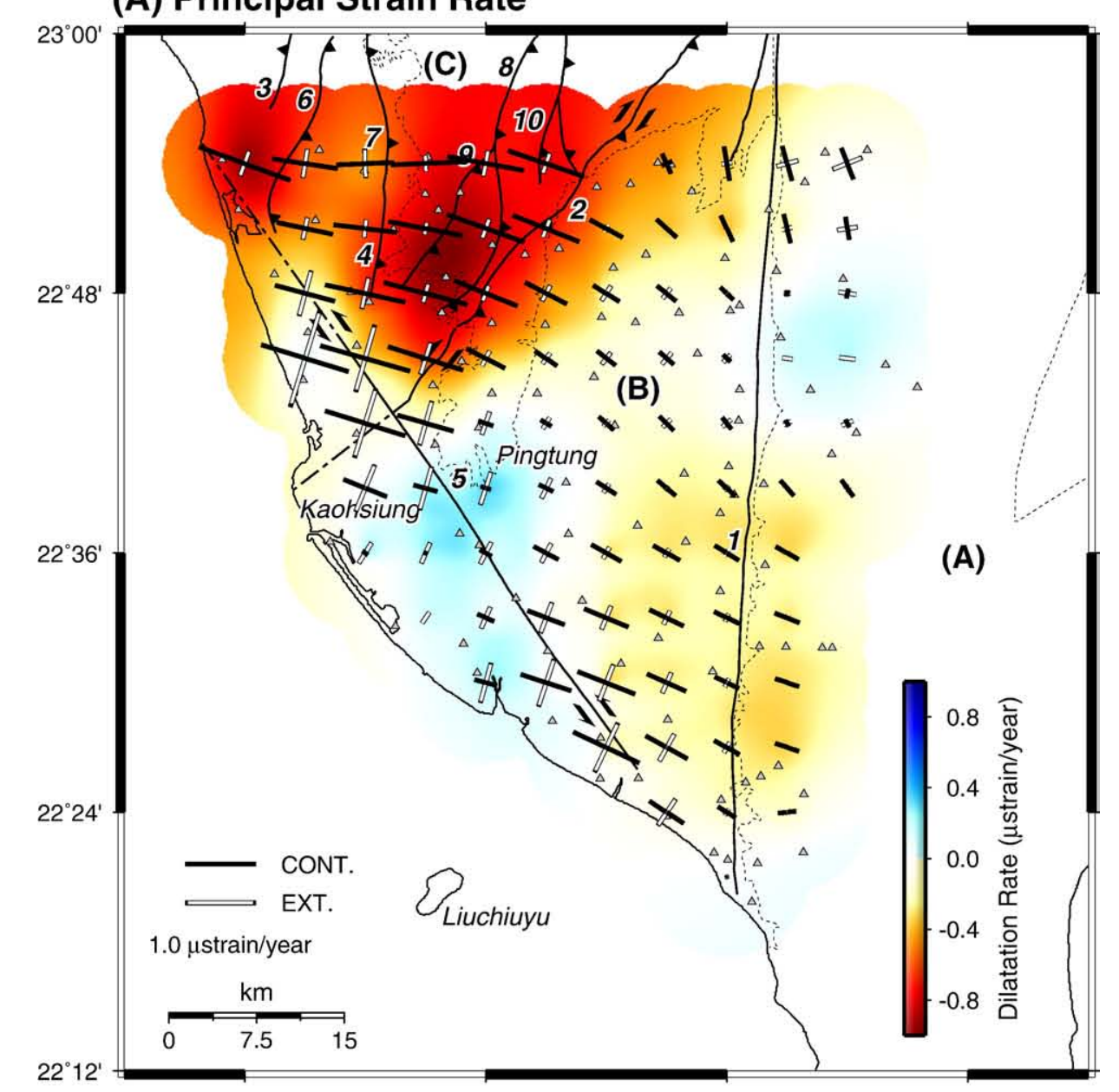

(B) Maximum Shear Strain Rate

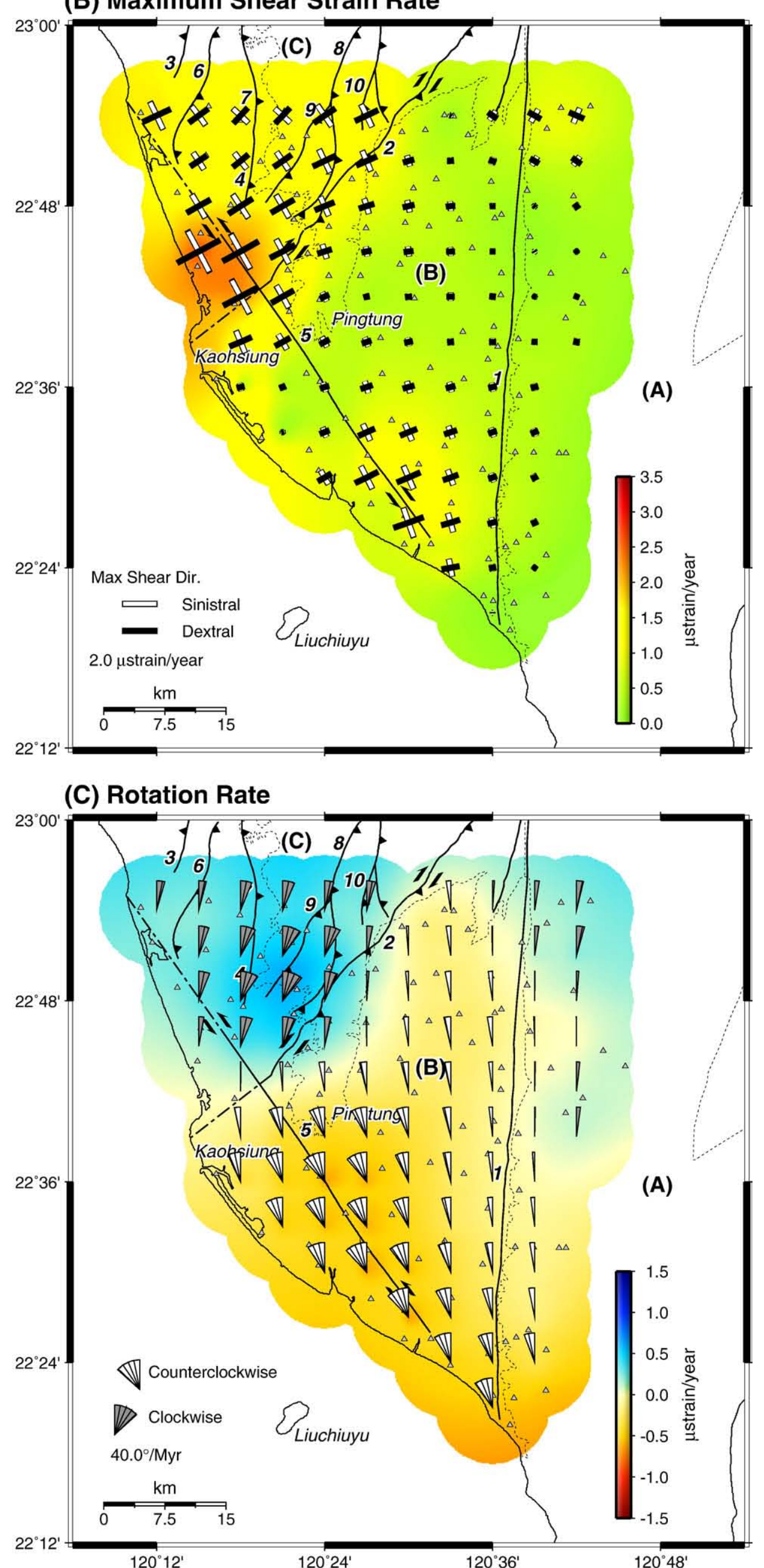

Fig. 6. Distribution of strain rates in SW Taiwan. (A) Horizontal dilatation strain rates with the principal strain axes. The thick bars reflect the amoun strain. Thick bars denote the rates. The amount of rotation rates are measured from the north with a cone shape The color scale represents the magnitudes of rotation rites Triangles are locations of GPS stations. Black lines are locations of active faults. (For interpretation of the references to color in this figure legend, the reader is referred to the web version of this article.) 


\subsection{GPS velocity field of SW Taiwan}

The GPS velocity field for all 103 stations in SW Taiwan (Fig. 3) is with respect to a stable continental margin station, S01R, at Penghu Island (Fig. 1). The GPS velocity field was estimated using daily coordinates from July 1995 to August 2005. Our results of velocities are in general comparable with the previous GPS results of 1990-1995 (red vectors in Fig. 3) (Yu et al., 1997) and those between 1995 and 1999 (green vectors in Fig. 3) (Hu et al., 2007), but are much more detailed. The pattern of the velocity field indicates a counterclockwise rotation in SW Taiwan. According to the variations of the velocities, SW Taiwan can be divided into two areas along the Chishan fault. For the stations west of the Chishan fault (in the Western Foothills and the coastal plain), station velocities decrease rapidly westwards of about $29 \mathrm{~mm} / \mathrm{yr}$ from $42.0 \mathrm{~mm} / \mathrm{yr}$ to $13.0 \mathrm{~mm} / \mathrm{yr}$ and azimuths show a small variation from $246^{\circ}$ to $265^{\circ}$ with a slight clockwise rotation pattern. In contrast, for the stations east of the Chishan fault in the Pingtung plain and the Central Range, most (about 95\%) station velocities are quite consistent $(51.9 \pm 6.6 \mathrm{~mm} / \mathrm{yr})$ and the azimuths changed gradually from $277^{\circ}$ to $247^{\circ}$ with a clear pattern of counterclockwise rotation. In an attempt to better uncover the tectonic deformation from the rapid velocities in SW Taiwan, we re-constructed the velocity field of SW Taiwan relative to a permanent station, S23R, within the Pingtung plain, where the strain rate is small because of comparable station velocities within this region (Fig. 4A). In addition to the aforesaid discontinuity along the Chishan fault shown in Fig. 3, we noticed another remarkable velocity discontinuity, which closely follows the $\mathrm{N} 140^{\circ} \mathrm{E}$-trending FTFZ in SW coastal area. This discontinuity extends from west of the Chishan fault to the southern tip of the Pingtung plain for about $40 \mathrm{~km}$.

Our GPS velocity field results indicate substantial subsidence occurs within the Pingtung plain area and uplift is distributed within the Western Foothills and the Central Range (Fig. 3). In more detail, the coastal area generally shows subsidence particularly north of Kaohsiung City (about $5 \mathrm{~mm} / \mathrm{yr}$ ) and the southernmost region of the Pingtung plain (about $20 \mathrm{~mm} / \mathrm{yr}$ ). In contrast, two areas with substantial uplift are present in the Central Range (20-30 mm/yr) and the area around the Chishan fault in the Western Foothills $(10-20 \mathrm{~mm} /$ yr). As a consequence, in addition to the Chishan fault and the FTFZ, the Chaochou fault represents a distinct discontinuity in SW Taiwan, with a significant vertical motion across the fault.
3.2. GPS profiles across major active faults of $S W$ Taiwan

The Kaoping fault, Chishan fault, FTFZ, and Chaochou fault are four dominant active fault systems in SW Taiwan (Lacombe et al., 2001; Hu et al., 2007). However, based on our resultant velocities, we cannot detect movement of the Kaoping fault because of a minor velocity gradient across this fault (Fig. 4A). Hence we doubt the existence of the Kaoping fault and do not discuss this fault below. To investigate activities of the other three fault systems, we decomposed horizontal velocities into the fault-parallel and faultperpendicular components to characterize the movement behaviors of these fault systems (Fig. 5).

In our GPS data, the horizontal velocities across the Chaochou fault from west to east mainly vary between 0 and $6 \mathrm{~mm} / \mathrm{yr}$ with an insignificant velocity gradient (Fig. 5A). On the other hand, we are able to discern that vertical velocities gradually increase across the fault from slight subsidence to uplift of about $20 \mathrm{~mm} / \mathrm{yr}$ (Fig. 5A), albeit the uncertainty of vertical GPS velocities is large. As a result, we concluded that the Central Range is moving upward with respect to the Pingtung plain and indicates that the Chaochou fault is a high-angle reverse fault. A slight horizontal velocity gradient across the fault shows that the Chaochou fault might be locked at the shallow portion at the present.

Along the profile across the Chishan fault, the faultparallel components of the GPS horizontal velocities gradually decrease from $13 \mathrm{~mm} / \mathrm{yr}$ to $-3 \mathrm{~mm} / \mathrm{yr}$ from NW to SE (the negative sign indicates southwestward motion; Fig. 5B). As a consequence, an evident dextral motion is estimated for about $10 \mathrm{~mm} / \mathrm{yr}$ across the Chishan fault. On the other hand, for the fault-normal components, velocities diminish from $22 \mathrm{~mm} / \mathrm{yr}$ to $5 \mathrm{~mm} / \mathrm{yr}$ across the profile, that is, a shortening rate of about $17 \mathrm{~mm} / \mathrm{yr}$ is uncovered across the Chishan fault. Finally, the variation of vertical velocities across the fault is too large to distinguish the vertical motion of the Chishan fault. We thus conclude that the Chishan fault is acting now as an oblique reverse faulting with a significant right-lateral strike-slip motion. The significant velocity contrast across the fault at a rather short distance of a few kilometers may reflect that the locking depth of the Chishan fault is shallow during the interseismic period.

Our GPS data show that a notable sinistral movement occurs along the FTFZ. In order to better quantify the movement along the FTFZ and not to mix it with the movements of active faults north of the Chishan fault, we present our GPS analyses south of the Chishan fault. In the horizontal velocity field, we observed a distinct left- 

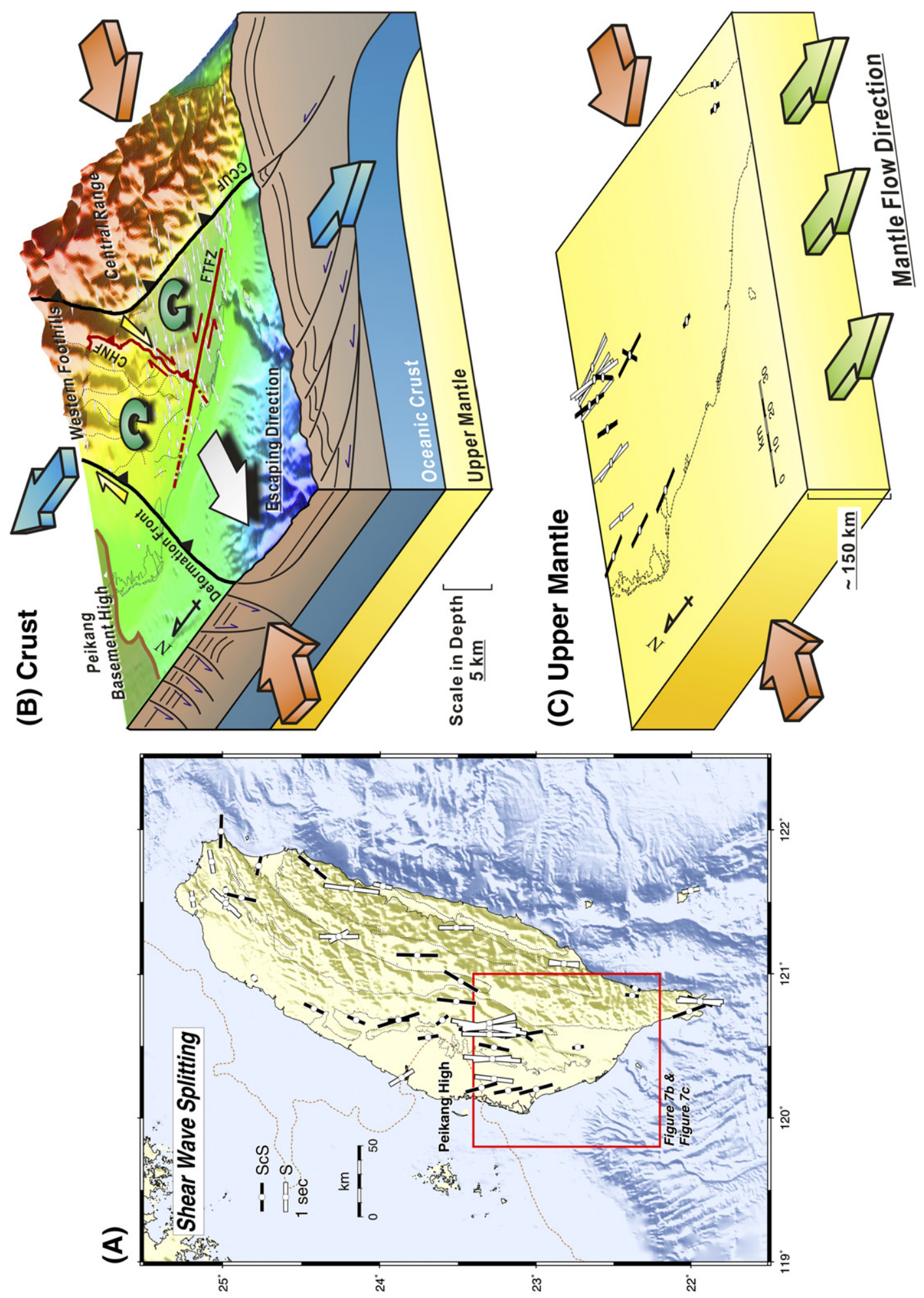
lateral motion of about $10 \mathrm{~mm} / \mathrm{yr}$ across the FTFZ according to the fault-parallel velocities (Fig. 5C). For the fault-perpendicular component, the velocity variation across the FTFZ demonstrates an undetectable deformation across the FTFZ, except for southwestward movements of about $9 \mathrm{~mm} / \mathrm{yr}$ in two stations (SASL and G157) resulting in a minor extension in the central part of the FTFZ. For the vertical velocity component, the displacement pattern shows no significant discrepancy occurring across the FTFZ. As a result, the FTFZ represents a nearly pure left-lateral transfer fault zone. According to the GPS velocity, the Fengshan transfer fault zone continues eastward across the whole southern Pingtung plain to the shoreline (Fig. 4B), which is greater distance than that previously proposed by Deffontaines et al. (1997). It seems that the FTFZ does not extend to the north of its intersection with the Hsiaokangshan fault (HKSF) and the Gutingkeng fault (GTKF), based on the GPS data. However, we cannot totally resolve this problem because of a sparse distribution of the GPS stations across the fault zone in the northern segment.

\section{The strain rate field in SW Taiwan}

Because the strain rate tensor is independent of the reference frame, the strain rate field shows an in situ local strain accumulation rate and possibly connects to a seismic hazard potential (Ward, 1994). We applied an interpolation technique proposed by Shen et al. (1996) to estimate distribution of strain rate according to the GPS velocity data. This method simulates strain rates as continuous functions within the entire network and assumes every calculation point to be a uniform strain rate field. In this study, the strain rate tensor of each calculation point is derived from the GPS velocities of more than four observation stations within a radius of $15 \mathrm{~km}$. Each included angle of the two nearest observation points is less than $180^{\circ}$ in order to make sure that the calculation point is located within the GPS network. According to the estimated strain rate tensor, we further calculated the principal strain rates, shear strain rates, dilatation strain rates, and rotation rates. The dilatation rate can be considered as a measure of the horizontal deformation related to dip-slip faulting (i.e., reverse faulting or normal faulting). On the other hand, a large shear strain rate is treated as mainly strike-slip faulting (Sagiya et al., 2000).

The resultant estimated dilatation rates with the principal axes of strain rates are shown in Fig. 6A. Upon a first approximation, the surface deformation of SW Taiwan was mainly characterized by dominant WNWESE shortening and NNE-SSW extension in two regions. A predominant contraction at a rate of $1.07 \pm 0.17 \mu$ strain/ $\mathrm{yr}$ in the direction of $\mathrm{N} 103^{\circ} \mathrm{E}$ occurred in the Western Foothills. A strain rate with both a large $\mathrm{N} 23^{\circ} \mathrm{E}$ extension at a rate of $0.68 \pm 0.20 \mu$ strain/yr and $N 113^{\circ} \mathrm{E}$ contraction at a rate of $0.52 \pm 0.15 \mu$ strain/yr occurs near the southern tip of the FTFZ. A strain with both notable contraction $\left(1.07 \pm 0.17 \mu\right.$ strain $/ \mathrm{yr}$ in $\left.\mathrm{N} 103^{\circ} \mathrm{E}\right)$ and lengthening $\left(1.02 \pm 0.34 \mu \mathrm{strain} / \mathrm{yr}\right.$ in $\left.\mathrm{N} 16^{\circ} \mathrm{E}\right)$ occurs near the northern termination of the FTFZ around Kaohsiung City. As for extension, a minor strain with a $\mathrm{N} 25^{\circ} \mathrm{E}$ extension at a rate of $0.38 \pm 0.13 \mu$ strain/yr is shown along the middle part of the FTFZ. For the remaining areas, the inferred dilatation rates range between $-0.47 \mu$ strain/yr and $0.34 \mu$ strain/yr near the Chaochou fault and most of the Pingtung plain.

Distributions of the estimated maximum shear strain rates and the principal axes of dextral and sinistral shear are shown in Fig. 6B. The maximum shear strain rates range from 0.06 to $2.73 \mu$ strain/yr in SW Taiwan. The northern portion of the Pingtung plain and the area along the Chaochou fault zone show relatively low shear strain rates of less than $0.98 \mu$ strain/yr. The large shear strain rates are mainly focused on three regions in SW Taiwan. First, a shear strain rate of $1.54 \pm 0.41 \mu$ strain/yr in $\mathrm{N} 66^{\circ} \mathrm{E}$ is interpreted to be a dominant right-lateral shear in the Western Foothills, especially west of the Chishan fault zone. Second, an obviously large sinistral shear strain $\left(1.20 \pm 0.31 \mu\right.$ strain $/ \mathrm{yr}$ in $\left.\mathrm{N} 157^{\circ} \mathrm{E}\right)$ is interpreted to be along the southern part of the FTFZ near the southern coastal area of the Pingtung plain. Third, the maximum shear strain rate of $2.73 \mu$ strain $/ \mathrm{yr}, \mathrm{N} 62^{\circ} \mathrm{E}$, occurs at the

\footnotetext{
Fig. 7. The tectonic kinematic model for SW Taiwan. (A) Shear-wave splitting for both S and ScS phase plotted as thick bars at stations. Fast polarization direction is given by bar azimuth from north. The delay time is proportional to the bar length. Red square is the location of $\mathrm{b}$ and $\mathrm{c}$. (B) The tectonic escape model for the crust. Large red arrows and blue arrows show the escaping-related stress regime of E-W shortening and N-S extension, respectively. Red lines reveal the conjugated-type fault system formed by the Chishan fault (CHNF) and the Fengshan transfer fault zone (FTFZ) in SW Taiwan. The large gray arrow denotes the crustal escaping direction. White thin arrows are GPS velocities from this study and Yu et al. (1997). Thin dashed lines are the locations of active faults. Yellow arrows represent the shear senses of transpression area (yellow area) in the fold-and-thrust belt between the deformation front and the Chishan fault (CHNF). The dark area reveals the location of quasi-rigid block of the Pingtung plain. Green arrows show the opposing rotation directions of the aforesaid two blocks. (C) The tectonic escape model for the upper mantle. Dashed lines show the projection of shorelines. Large arrows reveal the E-W contraction and green arrows represent the direction of upper mantle flow determined by shear-wave splitting, plotted as thick bars. Because the delay time is proportional to the bar length, the 1.5-second splitting time in SW Taiwan suggests an anisotropic layer thickness of $\sim 150 \mathrm{~km}$. (For interpretation of the references to color in this figure legend, the reader is referred to the web version of this article.)
} 
intersecting area among the FTFZ, the HKSF and the GTKF. Considering the possible activity of FTFZ, the shear strain is interpreted as a left-lateral movement, which is generally parallel to the left-lateral shear strain axes.

The rotation rate is derived from the asymmetric portion of the velocity gradient tensor and the positive rotation rate is considered to be a clockwise rotation (Fig. 6C). In general, rotation rates of $-36.2^{\circ} \mathrm{Myr}^{-1}$ to $32.9^{\circ} \mathrm{Myr}^{-1}$ are shown in SW Taiwan. Large rotation rates penetrate into two regions, bounded by the Chishan fault. First, the region west of the Chishan fault (i.e., the Western Foothills) is subject to a clockwise rotation averaging $19.8^{\circ} \pm 7.0^{\circ} \mathrm{Myr}^{-1}$. Second, counterclockwise rotation prevails in the southern portion of region east of the Chishan fault (i.e., the Pingtung plain) with the rate of $27.1^{\circ} \pm 6.4^{\circ} \mathrm{Myr}^{-1}$. In addition, the areas in the northern portion of the Central Range are slightly clockwise rotating with a rate of $4.6^{\circ} \pm 4.5^{\circ} \mathrm{Myr}^{-1}$ on average.

\section{Present-day kinematics in SW Taiwan}

On the basis of detailed analyses of the denselyspaced GPS measurements, we propose a revised tectonic kinematic model for the deformation in SW Taiwan (Fig. 7). Mechanisms are also suggested for the clockwise and counterclockwise deviations of velocity vectors in SW Taiwan.

First, in a broader regional scale, the convex Peikang basement high, acting as a rigid indenter, arrests the westward propagation of the frontal thrusts of the Taiwan mountain belt, due to the northwestward convergence of the Philippine Sea plate. As a result, the material in SW Taiwan is forced to extrude toward the WSW, subparallel to the edge of the basement high ( $\mathrm{Lu}$ and Malavieille, 1994; Lu et al., 1998). This mechanism contributes most of the portion of the counterclockwise deviation of velocity vectors in SW Taiwan based on the results from analogue and numerical modeling ( $\mathrm{Lu}$ and Malavieille, 1994; Lu et al., 1998; Yu and Chen, 1994).

Second, according to the GPS velocities and the yielded strain rates, the strong shortening, right-lateral shearing, and clockwise rotation are represented in the area between the deformation front and the Chishan fault (i.e., most parts of the Western Foothills) at the present time. On the contrary, the area of the Pingtung plain represents a relatively rigid block with much less deformation but a clear counterclockwise rotation. Therefore the Chishan fault, which apparently marks the major boundary between the deforming foothills and the rigid Pingtung plain, represents a major fault, separating two blocks with different mechanical properties. We interpret that the thick mudstone formation, a major feature in the Western Foothills west of the Chishan fault, is responsible for the weak mechanical property. On the other hand, the relative rigid PlioceneHolocene marine to fluvial sediments is filled in the Pingtung plain (Shyu, 1999; Chiang et al., 2004; Shyu et al., 2005). In addition, the strong dextral shear in the transpression zone between the deformation front and the Chishan fault tends to result in a clockwise rotation. In contrast, the counterclockwise rotation in the southern part area east of the Chishan fault is further enhanced by the sinistral shear of the FTFZ.

Third, the FTFZ probably develops from the late Pleistocene. The Pleistocene stress pattern in SW Taiwan shows that two different compressional stress regimes prevailed regionally in SW Taiwan (Lacombe et al., 1999). The early stress regime during Pleistocene showed noticeably NW-SE contractional and associated with the major stage of fold development. Then the following stress regime was a nearly E-W shortening, which corresponds to increasing component $\mathrm{N}-\mathrm{S}$ extension from north to south during the late Pleistocene. Compared to the Quaternary stress and present-day strain patterns, we found that the late Pleistocene stress pattern is generally consistent with the contemporary crustal strain pattern. The stress regime of ENE-WSW shortening and NNE-SSW extension was shown near the FTFZ and it may reflect the growth of the FTFZ. In addition, the left-lateral movement of $10 \mathrm{~mm} / \mathrm{yr}$ along the $\mathrm{N} 140^{\circ} \mathrm{E}$-striking $\mathrm{FTFZ}$ results in the velocities rotating from nearly westward direction within the Pingtung plain to WSW direction, parallel to the edge of Peikang high, along the SW coastline.

Finally, the NE-SW-trending Chishan fault and the N140 ${ }^{\circ}$ E-striking FTFZ form a conjugated-type fault system. The system agrees with the late Quaternary regional stress regime of an $\mathrm{E}-\mathrm{W}$ shortening and a perpendicular $\mathrm{N}-\mathrm{S}$ lengthening. This $\mathrm{E}-\mathrm{W}$ contraction is comparable with the late Pleistocene $\sigma 1$ paleostress trajectory in SW Taiwan (Lacombe et al., 1999; Lee and Angelier, 1994; Hu et al., 1996) and the present-day strain rate field in this study.

\section{Discussion}

Compared with the aforementioned tectonic escape hypotheses in SW Taiwan (Lu and Malavieille, 1994; Lu et al., 1998; Lacombe et al., 2001; Hu et al., 2007), our results of the velocity field in SW Taiwan agree with (1) the presence and shape of Peikang basement high acting as a rigid indenter; and (2) several thrusts in the 
foothills behaving as major weak discontinuities $(\mathrm{Hu}$ et al., 1997, 2001). However, previous studies mainly discuss the relationship between the escaping directions and escaping-parallel structures, assuming the trends of the structures are sub-parallel to the escape direction. Among three major active faults, only the Chishan reverse fault with dextral motion strikes sub-parallel to the escaping direction based on our present-day dense GPS observations (Fig. 5B). In contrast, the Chaochou reverse fault, and the left-lateral FTFZ strike at high angles to the escaping directions (Fig. 5A and C, respectively). We interpret that first, the escapingparallel Chishan fault and the escaping-normal FTFZ form a conjugated-type fault system, reflecting the stress regime of $\mathrm{E}-\mathrm{W}$ compression and $\mathrm{N}-\mathrm{S}$ extension in $\mathrm{SW}$ Taiwan (Fig. 7B). Second, the Chishan fault separates the SW Taiwan into two blocks: an internally deforming block in between the deformation front and the Chishan fault and a quasi-rigid block in between the Chishan fault and Chaochou fault (Fig. 7B). Third, our new dense GPS velocity field study indicates a large strain concentrating along the left-lateral FTFZ (Fig. 6B). Finally, in order to understand the relationship of the crustal deformation and the deformation in the upper mantle, we compared with the analysis of shear-wave splitting beneath Taiwan (Fig. 7A) (Rau et al., 2000). Orientations of the shearwave splitting in regional and teleseismic shear waves for the Taiwan stations are generally parallel to the strike of the mountain belt (Fig. 7A and C) (Rau et al., 2000). This nearly N-S-trending anisotropy in SW Taiwan seemingly represents the direction of mantle flow beneath the Taiwan orogen (Fig. 7A) (Rau et al., 2000). Comparison between the crustal deformation and the shear-wave anisotropy of lithospheric origin in SW Taiwan represents that the stress regime of nearly E$\mathrm{W}$ contraction and nearly $\mathrm{N}-\mathrm{S}$ extension prevails over the entire lithosphere (Fig. 7). In other words, the stress regime in SW Taiwan is exhibited in two different ways: by ductile flow in the upper mantle and by brittle conjugated-type fracture within the crust (Fig. 7).

For the tectonic escape in large-scale mountain belts, the directions of surface displacements, the sense of shear-wave splitting at the upper mantle, and the strikes of conjugated faults are approximately parallel to the tectonic escaping direction (Tikoff et al., 2004; Taylor et al., 2003). Therefore, the following mechanisms have been suggested to result in the deformation field of tectonic escape: (1) the indenter shape and convergence direction of collision between plates (Tapponnier et al., 1982; Rosenberg et al., 2007); and (2) gravity-driven flow dragging the crust because of the gravitational potential energy gradient ((Royden et al., 1997; Tikoff et al., 2004; Jones et al., 1996). However, for the case of tectonic escape in SW Taiwan, it is different from the aforesaid cases in Tibet and eastern Alps. The coeval E$\mathrm{W}$ contraction and $\mathrm{N}-\mathrm{S}$ extension prevails over the entire lithosphere that is accommodated by the kinematics of conjugated-type fault system in the crust and the ductile flow in the upper mantle (Fig. 7). The nearly $\mathrm{N}-\mathrm{S}$-trending shear-wave splitting reveals the escaping direction of mantle materials parallel to the strike of the Taiwan mountain belt (Fig. 7A and C). However, materials in upper crust escape to the WSW, striking at a high angle to the trend of the Taiwan mountain belt (Fig. 7B). In other words, the escaping tectonics in the crust is decoupled from the deformation in the upper mantle. The upper mantle flow implies the gravitational instability between the thickened crust and its adjacent foreland and hinterland. On the other hand, the crustal tectonic escape of SW Taiwan is mainly controlled by the geometry of the Chinese continental margin and not much affected by the deep-seated motion of the upper mantle.

\section{Conclusions}

Based upon annually repeated GPS observations from about $5 \mathrm{~km}$ station-spacing GPS network of 103 stations from 1995 to 2005, we characterized the present-day crustal deformation of escaping tectonics in SW Taiwan. The horizontal velocities with respect to a stable continental margin station, S01R, show from east to west a counterclockwise rotation from $42.0 \mathrm{~mm} /$ yr to $13.0 \mathrm{~mm} / \mathrm{yr}$ along the azimuths from $246^{\circ}$ to $265^{\circ}$ across SW Taiwan. The vertical velocities in SW Taiwan indicate that the subsidence rate of 5 to $20 \mathrm{~mm} / \mathrm{yr}$ is concentrated on the coastal area north of Kaohsiung City and especially the southernmost area of the Pintung plain. The uplift rate of 10 to $20 \mathrm{~mm} / \mathrm{yr}$ is distributed in the Western Foothills and the Central Range. Large strain rates are revealed in the area west of the Chishan fault and the region along the FTFZ. The remnant region shows little deformation. According to the analyses of velocity profiles and strain rate field, the Chaochou fault is acting as high-angle reverse faulting with the shallow part of the fault locked during the interseismic period. The Chishan fault is acting as oblique reverse faulting with significant right-lateral strike-slip motion. The Fengshan transfer fault zone (i.e., the FTFZ) shows a sinistral movement, and extends from the southern tip of the Hsiaokangshan fault and the Gutingkeng fault southeastward to the shoreline of the Pingtung plain.

Based upon analyses of detailed GPS observations, we propose a revised tectonic kinematic model for the 
crustal deformation in SW Taiwan. Interaction between the convex Peikang basement high and westward propagation of the accretionary wedge forces the material in SW Taiwan to escape toward WSW and SW, sub-parallel to the edge of the Peikang basement high. The Chishan fault represents a major boundary fault, separating the SW Taiwan into two structural domains: the internally deforming Western Foothills of right-lateral transpression with a clockwise rotation to the west and the relatively rigid Pingtung plain with a counterclockwise rotation to the east. The FTFZ probably began to develop from the late Pleistocene based on the comparison between Pleistocene stress and contemporary strain rate patterns. The counterclockwise rotation of velocity field in SW Taiwan is partly accommodated by the left-lateral faulting of about $10 \mathrm{~mm} / \mathrm{yr}$ along the $\mathrm{N} 140^{\circ} \mathrm{E}$-striking FTFZ. Finally, the stress regime of $\mathrm{E}-\mathrm{W}$ shortening and $\mathrm{N}-\mathrm{S}$ lengthening in SW Taiwan, induced by plate convergence and the lateral spreading of mountain belt, is demonstrated at different depths of the lithosphere: by southward ductile flow in the upper mantle and by a brittle conjugated-type fault system of the NE-SE-striking Chishan fault and the $\mathrm{N} 140^{\circ}$ E-striking FTFZ within the crust. In the tectonic escape process of SW Taiwan, the southward upper mantle flow and the southwestward crustal escape imply that the crust and upper mantle are decoupled.

\section{Acknowledgments}

We thank the Central Geological Survey (CGS) of Taiwan for the campaign-surveyed GPS data and MOI, IESAS, NCKU, and IGS for continuous GPS data. We thank Kaj Johnson, Michael Hamburger, and Timothy Byrne for many helpful suggestions. We thank an anonymous reviewer for helpful comments. Figures were generated using the Generic Mapping Tools (GMT), developed by Wessel and Smith (1991). This research was partially supported by CGS 5226902000-02-95-03 and NSC 95-2119-M-006-002 and 96-2116-M-006-011.

\section{Appendix A. Supplementary data}

Supplementary data associated with this article can be found, in the online version, at doi:10.1016/j. eps1.2007.08.017.

\section{References}

Angelier, J., Lee, J.C., Chu, H.T., Lu, C.Y., Fournier, M., Hu, J.C., Lin, N.T., Deffontaines, B., Delcaillau, B., Lacombe, O., Lee, T.Q.,
1995. Crustal extension in an active orogen: Taiwan. In: Tsien, H.-H. (Ed.), ACT Int. Conf., Extended. Abstr. Geol. Soc. China Spec. Publ., Taipei, Taiwan, pp. 25-32.

Agnew, D.C., 1992. The time-domain behavior of power-law noises. Geophys. Res. Lett. 19, 333-336.

Altamimi, Z., Sillard, P., Boucher, C., 2002. ITRF2000: a new release of the International Terrestrial Reference Frame for earth science applications. J. Geophys. Res. 107. doi:10.1029/2001JB000561.

Biq, C.C., 1972. Dual-trench structure in Taiwan-Luzon region. Proc. Geol. Soc. China 15, 65-75.

Bonilla, M.G., 1977. Summary of Quaternary faulting and elevation changes in Taiwan. Mem. Geol. Soc. China 2, 43-56.

Crespi, J.M., Chan, Y.C., Swaim, M.S., 1996. Synorogenic extension and exhumation of the Taiwan hinterland. Geology 3, 247-250.

Y.C. Chan, J.C. Lee, C.Y. Lu, H.T. Chu, Transtensional tectonics along a major north-south trending fault in the active convergent Taiwan mountain belt, EOS Trans. AGU 82(47) Fall Meet. Suppl. (2001) F1179.

Chiang, S.C., 1971. Seismic study of the Chaochou structure, Taiwan. Pet. Geol. Taiwan 8, 281-294.

Chiang, C.S., Yu, H.S., Chou, Y.W., 2004. Characteristics of the wedge-top depozone of the southern Taiwan foreland basin system. Basin Res. 16, 65-78.

Deffontaines, B., Lacombe, O., Angelier, J., Mouthereau, F., Lee, C.T., Deramond, J., Lee, J.F., Yu, M.S., Liu, P.M., 1997. Quaternary transfer faulting in Taiwan Foothills: evidence from a multisource approach. Tectonophysics 274, 61-82.

Howard, A.D., 1962. The Chungchou photogeologic anomaly. Pet. Geol. Taiwan 1, 121-125.

Hu, J.C., Angelier, J., Lee, J.C., Chu, H.T., Byrne, D., 1996. Kinematics of convergence, deformation and stress distribution in the Taiwan collision area: 2-D finite-element numerical modeling. Tectonophysics 255, 243-268.

Hu, J.C., Angelier, J., Yu, S.B., 1997. An interpretation of the active deformation of southern Taiwan based on numerical simulation and GPS studies. Tectonophysics 274, 145-169.

Hu, J.C., Yu, S.B., Angelier, J., Chu, H.T., 2001. Active deformation of Taiwan from GPS measurements and numerical simulations. J. Geophys. Res. 106, 2265-2280.

Hu, J.C., Hou, C.S., Shen, L.C., Chan, Y.C., Chen, R.F., Huang, C., Rau, R.J., Chen, K.H., Lin, C.W., Huang, M.H., Nien, P.F., 2007. Fault activity and lateral extrusion inferred from velocity field revealed by GPS measurements in the Pingtung area of southwestern Taiwan. J. Asian Earth Sci. doi:10.1016/j.jseaes.2006.07.020.

Hugentobler, U., Schaer, S., Fridez, P. (Eds.), 2001. Bernese GPS Software Version 4.2. Astronomical Institute, University of Berne. $515 \mathrm{pp}$.

Jones, C.H., Unruh, J.R., Sonder, L.J., 1996. The role of gravitational potential energy in active deformation in the southwestern United States. Nature 381, 37-41.

Lacombe, O., Mouthereau, F., Deffontaines, B., Angelier, J., Chu, H.T., Lee, C.T., 1999. Geometry and Quaternary kinematics of fold-andthrust units of southwestern Taiwan. Tectonics 18, 1198-1223.

Lacombe, O., Mouthereau, F., Angelier, J., Deffontaines, B., 2001. Structural, geodetic and seismological evidence for tectonic escape in SW Taiwan. Tectonophysics 333, 323-345.

T.H. Lai, M.L. Hsieh, P.M. Liew, Y.G. Chen, Holocene rock uplift and subsidence in the coastal area of Taiwan. EOS Trans. AGU 83(47) Fall Meet. Suppl. (2002) F1280.

Lai, T.H., Hsieh, M.L., 2003. Late-Quaternary Vertical RockMovement Rates of the Coastal Plains of Taiwan, 2003 Annual Meeting Geological Society, Taipei, p. 119. 
Langbein, J., Johnson, H., 1997. Correlated errors in geodetic time series: implications for time-dependent deformation. J. Geophys. Res. 102, 591-604.

Lee, J.C., Angelier, J., 1994. Paleostress trajectory maps based on the results of local determinations: the 'LISSAGE' program. Comput. Geosci. 20, 161-191.

Lewis, C., Chen, S.W., Yen, P.C., 2004. Magnetic surveying of the Chaochou fault of southern Taiwan: culmination of basementinvolved surface thrusting in arc-continent collision. Int. Geol. Rev. 46, 399-408.

Lin, A.T., Watts, A.B., 2002. Origin of the west Taiwan basin by orogenic loading and flexure of a rifted continental margin. J. Geophys. Res. 107, 2185-2203.

Lin, A.T., Watts, A.B., Hesselbo, S.P., 2003. Cenozoic stratigraphy and subsidence history of the South China Sea margin in the Taiwan region. Basin Res. 15, 453-478.

Liu, C.S., Huang, I.L., Tseng, L.S., 1997. Structural features of southwestern Taiwan. Mar. Geol. 137, 305-319.

Lu, C.Y., Malavieille, J., 1994. Oblique convergence, indentation and rotation tectonics in the Taiwan Mountain Belt: insights from experimental modeling. Earth Planet. Sci. Lett. 121, 477-494.

Lu, C.Y., Jeng, F.S., Chang, K.J., Jian, W.T., 1998. Impact of basement high on the structure and kinematics of western Taiwan thrust wedge: insights from sandbox models. Terr. Atmos. Ocean Sci. 9, 533-550.

Meng, C.Y., 1967. The structural development of the southern half of western Taiwan. Proc. Geol. Soc. China 10, 77-82.

Mouthereau, F., Deffontaines, B., Lacombe, O., Angelier, J., 2002. Variation along the strike of the Taiwan thrust belt: basement control on structural style, wedge geometry, and kinematics. Geol. Soc. Am. 358, 31-54 Special Paper.

Ratschbacher, L., Frisch, W., Linzer, H.G., Merle, O., 1991. Lateral extrusion in the Eastern Alps, 2. Structural analysis. Tectonics 10, $257-271$

Rau, R.J., Wu, F.T., 1998. Active tectonics of Taiwan orogeny from focal mechanisms of small-to-moderate-sized earthquakes. Terr. Atmos. Ocean Sci. 9, 755-778.

Rau, R.J., Liang, W.T., Kao, H., Huang, B.S., 2000. Shear wave anisotropy beneath the Taiwan orogen. Earth Planet. Sci. Lett. 177, $177-192$

Rosenberg, C.L., Brun, J.P., Cagnard, F., Gapais, D., 2007. Oblique indentation in the Eastern Alps: insights from laboratory experiments. Tectonics 26. doi:10.1029/2006TC001960.

Royden, L.H., Burchfiel, B.C., King, R., Chen, Z., Shen, F., Liu, Y., 1997. Surface deformation and lower crustal flow in eastern Tibet. Science 276, 788-790.

Sagiya, T., Miyazaki, S., Tada, T., 2000. Continuous GPS array and present-day crustal deformation of Japan. PAGEOPH 157, 2303-2322.

Shen, Z.K., Jackson, D.D., Ge, B.X., 1996. Crustal deformation across and beyond the Los Angeles basin from geodetic measurements. J. Geophys. Res. 101, 27957-27980.
Shyu, B.S., 1999. The sedimentary environment of southern Pingdong plain since the last glacial, Master Thesis, National Taiwan University, Taipei, 212 pp.

Shyu, J.B.H., Sieh, K., Chen, Y.G., Liu, C.S., 2005. Neotectonic architecture of Taiwan and its implications for future large earthquakes. J. Geophys. Res. 110. doi:10.1029/2004JB003251.

Suppe, J., 1984. Kinematics of arc-continent collision, flipping of subduction and back-arc spreading near Taiwan. Mem. Geol. Soc. China 6, 21-33.

Tabei, T., Amin, W.L., 2002. Common-mode errors in the GPS coordinates time series - application of spatial filtering technique. J. Geod. Soc. Jpn. 48, 229-241.

Tapponnier, P., Peltzer, G., Le Dain, A.Y., Armijo, R., Cobbold, P., 1982. Propagating extrusion tectonics in Asia; new insights from simple experiments with plasticine. Geology 10, 611-616.

Taylor, M., Yin, A., Ryerson, F.J., Kapp, P., Ding, L., 2003. Conjugate strike-slip faulting along the Bangong-Nujiang suture zone accommodates coeval east-west extension and north-south shortening in the interior of the Tibetan Plateau. Tectonics 22. doi:10.1029/2002TC001361.

Tikoff, B., Russo, R., Teyssier, C., Tommasi, A., 2004. Mantle-driven deformation of orogenic zones and clutch tectonics. In: Grocott, J., McCaffrey, K.J.W., Taylor, G., Tikoff, B. (Eds.), Vertical Coupling and Decoupling in the Lithosphere, vol. 227. Geological Society, London, pp. 41-64. Special Publications.

Tsan, S.F., Keng, W.P., 1968. The Neogene rocks and major structural features of southwestern Taiwan. Proc. Geol. Soc. China 11, $45-59$.

Ward, S.N., 1994. A multidisciplinary approach to seismic hazard in southern California. Bull. Seism. Soc. Am. 84, 1293-1309.

Wessel, P., Smith, W., 1991. Free software helps map and display data, Eos Trans. AGU 72(441) 445-446.

Wdowinski, S., Bock, Y., Zhang, J., Fang, P., Genrich, J., 1997. Southern California permanent GPS geodetic array: spatial filtering of daily positions for estimating coseismic and postseismic displacements induced by the 1992 Landers earthquake. J. Geophys. Res. 102, 18057-18070.

Wu, F.T., Rau, R.J., Salzberg, D.H., 1997. Taiwan orogeny: thinskinned or lithospheric collision. Tectonophysics 274, 191-220.

Yeh, Y.H., Barrier, E., Lin, C.H., Angelier, J., 1991. Stress tensor analysis in the Taiwan area from focal mechanisms of earthquakes. Tectonophysics 200, 267-280.

Yu, S.B., Chen, H.Y., 1994. Global positioning system measurements of crustal deformation in the Taiwan arc-continent collision zone. Terr. Atmos. Ocean Sci. 5, 477-498.

Yu, S.B., Chen, H.Y., Kuo, L.C., 1997. Velocity field of GPS stations in the Taiwan area. Tectonophysics 274, 41-59. 